University of Rhode Island

DigitalCommons@URI

The Rhode Island Current Conditions Index

Economics

$12-2016$

\title{
Rhode Island Current Conditions Index - December 2016
}

Leonard Lardaro

University of Rhode Island, lardaro@uri.edu

Follow this and additional works at: https://digitalcommons.uri.edu/ricci

Part of the Econometrics Commons

Terms of Use

All rights reserved under copyright.

\section{Recommended Citation}

Lardaro, Leonard, "Rhode Island Current Conditions Index -- December 2016" (2016). The Rhode Island Current Conditions Index. Paper 156.

https://digitalcommons.uri.edu/ricci/156

This Article is brought to you for free and open access by the Economics at DigitalCommons@URI. It has been accepted for inclusion in The Rhode Island Current Conditions Index by an authorized administrator of DigitalCommons@URI.For more information, please contact digitalcommons-group@uri.edu. 


\title{
CURRENT CONDITIONS
}

\section{LEONARD LARDARO, URI}

\author{
Available Online: http:/ / www .Ilardaro.com/ current.htm \\ Blog: http:/ / rieconomy.blogspot.com \\ Twitter: @ladardo
}

VOL XXIV

NUMBER 1

DEC 2016
Rhode Island's economy ended the year on a very positive note: the Current Conditions Index reached its highest value for all of 2016 in December, 83, as ten of the twelve $\mathrm{CCl}$ indicators improved. For the second half of 2016, the CCl essentially remained at or around a level of 75, something we haven't seen very often during this recovery.

Rhode Island's second-half performance is highly noteworthy in light of the variation in the quality of our state's economic performance throughout 2016. Early on, Rhode Island stumbled badly, even though the national economy encountered only a short-term blip in its growth rate. Recently released data on state GDP indicate that Rhode Island's second quarter growth rate fell all the way to 0.2 percent, indicating that its economy essentially flat lined. This eye-opening performance must serve as a warning to everyone here that Rhode Island's economy remains far too susceptible to downdrafts in national economic momentum and that a relatively large number of structural changes remain that must be undertaken. Our state's third quarter performance saw real GDP growth of 3.6 percent. On the surface, that appears to be an excellent growth rate, except for one thing: These growth rates are sequential, so the +3.6 percent is relative to the barely positive +0.2 percent from Q2. Averaging these gives growth of 1.9 percent - not terrible, but, as the saying goes, nothing to write home about.

The escalating momentum indicated by the Current Conditions Index during the fourth quarter appears to indicate that Rhode Island's economy very likely returned to a rate of growth higher

\begin{tabular}{|l|r|r|}
\hline \multicolumn{3}{|c|}{ CCI Indicators - \% Change } \\
\hline Government Employment & 1.5 & $\mathbf{Y}$ \\
\hline US Consumer Sentiment & 6.2 & $\mathbf{Y}$ \\
\hline Single-Unit Permits & 44.1 & $\mathbf{Y}$ \\
\hline Retail Sales & -2.1 & \\
\hline Employment Services Jobs & -1.9 & \\
\hline Priv. Serv-Prod Employment & 1.1 & $\mathbf{Y}$ \\
\hline Total Manufacturing Hours & 4.2 & $\mathbf{Y}$ \\
\hline Manufacturing Wage & 6.1 & $\mathbf{Y}$ \\
\hline Labor Force & 0.2 & $\mathbf{Y}$ \\
\hline Benefit Exhaustions & -10.7 & $\mathbf{Y}$ \\
\hline New Claims & -0.2 & $\mathbf{Y}$ \\
\hline Unemployment Rate (change) & -0.4 & $\mathbf{Y}$ \\
\hline \multicolumn{2}{|c|}{ Y = Improved Value } \\
\hline
\end{tabular}

than 2 percent. In addition to this, while the labor market data for the last two months of 2016 appear to be highly negative, with numerous uptrends seemingly reversing, history shows that as November and December are the two months farthest from "known" data values, they are the most likely months to be revised when the January data are released.

This is quite possible (and hopeful) for Employment Service Jobs, which includes temporary employment and is a leading indictor of future employment. Current data show this indicator falling sharply for both November $(-3.9 \%)$ and December $(-1.9 \%)$ and in a downtrend since March. Deterioration in this indicator would be troubling if the disappointing data are confirmed with data revisions. We'll have to wait to see what happens.

That brings us to December's report. The CCI rose nicely from 67 to 83. Notably, the $\mathrm{CCl}$ has matched or exceeded its year-earlier values for every month since July. This too is reflective of increasing economic momentum. For December, four of the five leading indicators contained in the $\mathrm{CCl}$ improved. The one that failed to improve, as noted above, was Employment Service Jobs. For once, both indicators reflecting Rhode Island's goodsproducing sector improved. Total Manufacturing Hours, a proxy for manufacturing output, went from flat in September to improving at increasing rates for the most recent three months, related largely to a longer workweek. Single-Unit Permits rose sharply this month $(+44.1 \%)$, powered in part by a very easy comp one year ago.

US Consumer Sentiment improved in December $(+6.2 \%)$ for only the first time in the last four months. New Claims, the most timely measure of layoffs, barely improved $(+0.2 \%)$.

Government Employment remained above 60,000, Iargely the result of rising federal government employment. Our Labor Force has now improved on a yearly basis for the most recent five months, following twenty-six consecutive months of declines. On a monthly basis, the Labor Force fell sharply again, so the December Unemployment Rate decline to 5 percent should be largely dismissed. Private Service-Producing Employment growth moderated $(+1.1 \%)$, while Benefit Exhaustions improved strongly in December, sustaining its downtrend.
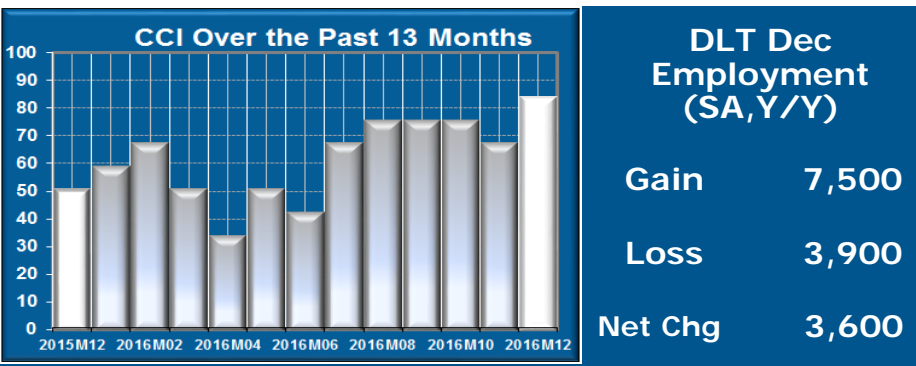

THE BOTTOM LINE

This report coincides with the tenth anniversary of our prior payroll employment peak. The year 2017 also represents another anniversary for us: The 30th anniversary of Rhode Island's transition from a manufacturing to a post-manufacturing economy. Although we are moving in the right direction, especially with our improved momentum at year's end, the pace of our progression remains far too slow, as evidenced by our Q2 performance. If we wish to sustain our enhanced cyclical momentum, it will be necessary for us to continue reinventing our state's economy, based on well-defined and sustained structural changes. Is our state government up to the task?

\begin{tabular}{c|c|c|c|c|c|c|c|c|c|c|c|c|c|}
\hline 5 & Jan & Feb & Mar & Apr & May & J un & Jul & Aug & Sep & Oct & Nov & Dec \\
\hline \multirow{2}{*}{2015} & $67 \uparrow$ & $67 \uparrow$ & 67 & $67 \uparrow$ & 67 & $67 \downarrow$ & $58 \downarrow$ & $75 \downarrow$ & $67 \downarrow$ & $50 \downarrow$ & $67 \downarrow$ & $50 \downarrow$ \\
\cline { 2 - 12 } & 2016 & 58 & 67 & $50 \downarrow$ & 42 & 50 & 42 & $67 \uparrow$ & 75 & 75 & 75 & 67 & 83
\end{tabular}

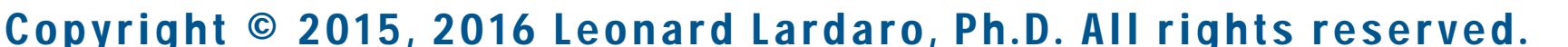

